\title{
Lectotypification of Eriocaulon xeranthemum (Eriocaulaceae)
}

\author{
Paithane V.A. ${ }^{1 *}$, Bhuktar A.S. ${ }^{2}$, Lakshminarasimhan P. ${ }^{3}$ \& V. Prasanna ${ }^{4}$ \\ ${ }^{1}$ Department of Botany Anandibai Raorane Arts, Commerce and Science College, Vaibhavwadi, Sindhudurg. \\ ${ }^{2}$ Vivekanand Arts, S.D. Commerce and Science College, Aurangabad, Maharashtra. \\ ${ }^{3}$ Western Circle, Botanical Survey of India, Pune, Maharashtra. \\ ${ }^{4}$ Central National Herbarium, Botanical Survey of India, Kolkata, West Bengal. \\ *E-mail: tiliaceae20384@gmail.com
}

\begin{abstract}
A specimen at CAL is designated here as the second-step lectotype of the name Eriocaulon xeranthemum Mart.
\end{abstract}

Keywords: Eriocaulon xeranthemum, Second-step lectotypification.

\section{Introduction}

Martius (1832) in the protologue of Eriocaulon xeranthemum Mart. cited two specimens viz., 'Cresit in Napalia (N. Wallich 1821), in Tavoy ( $W$. Gomez)'. Ansari and Balakrishnan (1994) cited the type as 'Wallich Cat. no. 6981, Nepal 1821 (? BR holotype; CAL, $\mathrm{K}$ isotypes)'. The cited number 6981 is evidently a typographical error because in the other two pages (Ansari \& Balakrishnan, 1994: $59,60)$ they have correctly given the number as '6081'.

According to Stafleu and Cowan (1981), Martius' own collections from Brazil (1817-1820), including the types of the names of most of his Brazilian species, are at München (M), often with very scanty annotations. In addition, $M$ has collections made by Martius in the Mediterranean area and Madeira. Martius' herbarium, including the types of the names of his species based on other collections, is at BR.

Ansari and Balakrishnan (1994) must have been aware that the main type is at BR. They did not see the type and so cited as BR. The citation of holotype is obviously an error on their part but it can be corrected to lectotype under Art. 9.10 (Turland et al., 2018). There is indeed a relevant sheet at BR. On the right

Received: 25.10.2018; Revised \& Accepted: 25.03.2019

Published Online: 30.06 .2019 side of the sheet there seems to be a gathering from Tavoy by W. Gomez (BR0000009185838 image!). On the left side of the sheet a gathering is pasted from Napalia (Nepal) collected in 1821 (BR0000009187283 image!). However, there is no clear cut demarcation between the two gatherings. Moreover, in a letter pasted on this sheet written to Martius, dated $17^{\text {th }}$ January 1832 , Wallich wrote 'These spec'-are from the Mts. Sillet. I received them some months ago...' Thus it becomes more difficult to ascertain which of the plants are of the same gathering from Nepal.

According to the Kew Herbarium Catalogue, there are two relevant sheets (Nepalia, 1821, Wall. Cat. no. 6081) at K (K000098640 image!; K001122961 image!). K000098640 is represented by a single plant marked by someone as ' $A$ ' and K001122961 by a gathering of five plants, all of them marked by someone as ' $A$ ' but from the publication of Ansari and Balakrishnan (1994) it cannot be ascertained that they have examined these specimens or not. On the other hand Ansari and Balakrishnan (1994) have stated 'NEPAL: Wallich, Cat. no. 6081 (CAL type)' under 'specimens examined'. We are accepting here the CAL specimen as the lectotype under Art. 7.11 (Turland et al., 2018), inadvertently designated by Ansari and Balakrishnan (1994). However, there are three such specimens at CAL collected by Wallich from Nepal in 1821 (CAL0000025845, CAL0000025846, CAL0000025847) and it cannot be arrived to a conclusion which specimen is cited as the type by Ansari and Balakrishnan (1994). So these are to be accepted as the first-step lectotype and a second-step lectotype (see Turland et al., 2018, Art. 9.17) is selected here. 


\section{Typification}

Eriocaulon xeranthemum Mart. in Wall., Pl. Asiat. Rar. 3(10): 29. 1832.

Lectotype (Step I, designated by Ansari \& Balakrishnan, 1994): NAPALIA, 1821, Wall. Cat. no. 6081 (CAL0000025845!, CAL0000025846!, CAL0000025847!).

Lectotype (Step II, designated here): NAPALIA, 1821, Wall. Cat. no. 6081 CAL0000025846!; isolectotypes CAL0000025845!, CAL0000025847!).

Fig. 1

\section{Acknowledgements}

Authors are grateful to Director, Botanical Survey of India, Kolkata for permission to use images of types; Dr. K.N. Gandhi (Harvard University Herbarium, USA), Dr. Subir Bandyopadhyay (Botanical Survey of India, Kolkata) for nomenclatural discussions and Curator of Herbarium Botanic Garden, Meise, Belgium (BR) for sending the images of type specimens.

\section{Literature Cited}

ANSARI R. \& N.P. BALAKRISHNAN 1994. The family Eriocaulaceae in India. Bishen Singh Mahendra Pal Singh, Dehra Dun. 58 p.

MARTIUS, C.F.P.VON 1832. Eriocaulon xeranthemum. In: WALLICH N. (ed.), Plantae Asiaticae Rariores or, descriptions and figures of a select number of unpublished East Indian plants. Volume 3(10). Treuttel \& Würtz, London. 29 p.

STAFLEU F.A. \& R.S. COWAN 1981. Taxonomic literature, Second edition. Volume 3. Bohn, Scheltema \& Holkema, Utrecht. pp. 325-339.

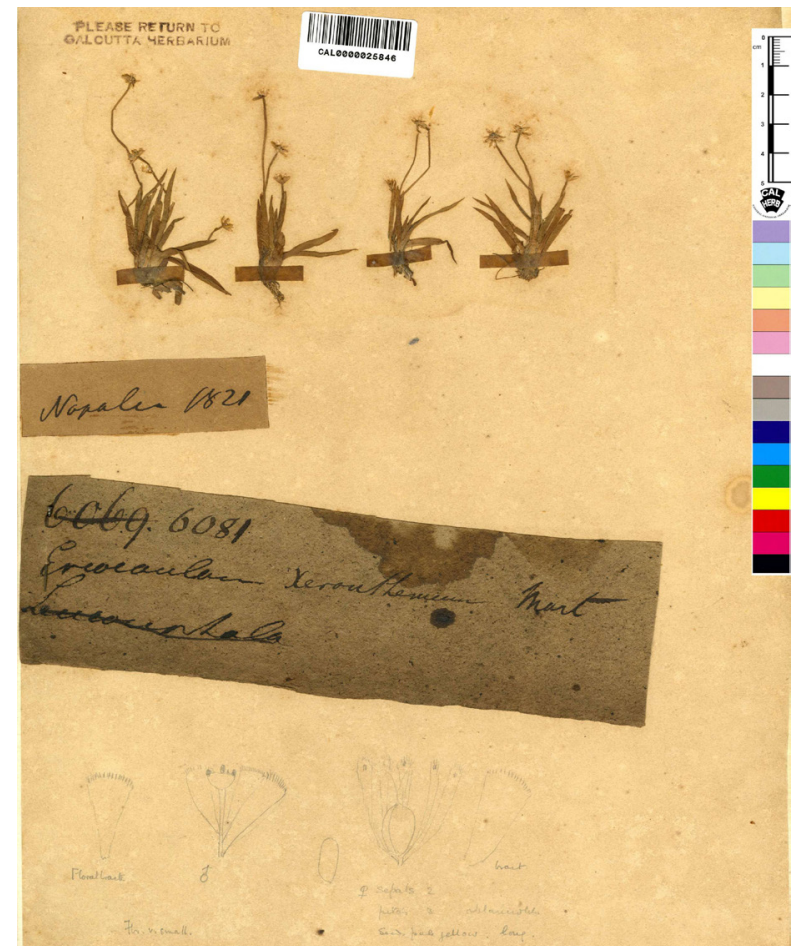

Fig.1. Lectotype of Eriocaulon xeranthemum (Napalia, 1821, Wall. Cat. no. 6081, CAL0000025846) @ Botanical Survey of India, Kolkata.

TURLAND N.J., WIERSEMA J.H., BARRIE F.R., GREUTER W., HAWKSWORTH D.L., HERENDEEN P.S., KNAPP S., KUSBER W.H., LI D.Z., MARHOLD K., MAY T.W., MCNEILL J., MONRO A.M., PRADO J., PRICE M.J. \& G.F. SMITH (eds.) 2018. International Code of Nomenclature for algae, fungi, and plants (Shenzhen Code) adopted by the Nineteenth International Botanical Congress Shenzhen, China, July 2017. Regnum Vegetabile 159. Glashütten: Koeltz Botanical Books. https://doi.org/10.12705/Code.2018. 